\title{
ПРОДУКТИВНІСТЬ СОЇ ЗАЛЕЖНО ВІД ЕЛЕМЕНТІВ ТЕХНОЛОГІЇ ВИРОЩУВАННЯ В УМОВАХ ПРАВОБЕРЕЖНОГО ЛІСОСТЕПУ УКРАЇНИ
}

\author{
п. С. ВИШНІВСьКИЙ, доктор сільськогосподарських наук \\ O.В. ФУРМАН, аспірант*, \\ Національний науковий центр «/нститут землеробства НААН» \\ E-mail: furmanov918@ukr.net \\ ORCID ID https://orcid.org/0000-0001-7130-005X
}

\begin{abstract}
Анотація. Значну роль у розв'язанні проблеми дефіциту рослинного білка відіграє соя, сучасні високопродуктивні сорти якої за розробки та удосконалення адаптивних складових технологій їі вирощування, здатні формувати стабільно високі врожаї якісного насіння. Серед таких складових велике значення має підбір сортів, уточнення норм удобрення та інокуляція насіння відповідно до грунтово-кліматичних умов конкретного регіону.

Мета досліджень полягала у виявленні особливостей формування продуктивності сої різних сортів залежно від інокуляції насіння та норм і строків внесення мінеральних добрив в умовах Лісостепу правобережного. Дослід закладали впродовж 2013-2015 рр. в умовах ДПДГ «Саливонківське» Інституту біоенергетичних культур і цукрових буряків НААН на чорноземах типових малогумусних.

За результатами досліджень встановлено, що в умовах правобережного Лісостепу України максимальну урожайність досліджувані сорти формували за умови поєднання обробки насіння перед проведенням сівби фосфонітрагіном та внесення $N_{30} P_{60} K_{60}$ в основне удобрення та підживленням рослин $N_{15}$ у фазі бутонізації, що дозволило отримати на посівах скоростиглого сорту Вільшанка 2,91 m/га, середньостиглого сорту Сузір'я - 3,17 m/га. Проти абсолютного контролю приріст урожаю на цих варіантах становив відповідно 1,02 ma 0,98 m/га.
\end{abstract}

Ключові слова: соя, сорт, інокуляція, підживлення, удобрення, урожайність

\section{Актуальність.}

Серед великої кількості сільськогосподарських культур соя належить до найважливіших високобілкових i олійних культур світового землероб- ства, завдяки чому їі посівні площі у світі продовжують зростати.

За вегетаційний період соя синтезує два врожаї - білка та жиру (60 \% від маси насіння) та майже всі органічні речовини, що $є$ в рослинному світі. Завдяки багатому й різноманіт-

\footnotetext{
* Науковий керівник - доктор сільськогосподарських наук Вишнівський П. С.
} 
ному хімічному складу, іiї використовують як універсальну, продовольчу, кормову й олійну культуру, що не має собі аналогів серед рослинних ресурсів як за продуктивністю, так і за якісним складом.

В Україні протягом останніх 10 років площі посівів сої зросли від 583 тис. га до 1,8 млн га. Збільшення виробництва соєвих бобів насамперед спрямоване на розв'язання проблеми рослинного білка та формування експортного потенціалу білкових ресурсів (Темрієнко О.О., 2018).

Крім того, вирощування сої сприяє включенню в процес сільськогосподарського виробництва атмосферного азоту, поліпшенню хімічних і фізичних властивостей грунту, покращенню фітосанітарного стану посівів та значному підвищенню продуктивності одиниці сівозмінної площі.

Нині, завдяки досягненням селекціонерів, з'явилися високотехнологічні, високопродуктивні і стійкі до хвороб сорти сої. Проте рівень реалізації потенціалу їхньої урожайності значною мірою обумовлюється грунтово-кліматичними умовами конкретної зони вирощування та адаптованою технологією вирощування (Бабич A.О. \& Бабич-Побережна А.А., 2011), що особливо актуально за останніх тенденцій зміни клімату (Мельник А. В. \& Романько Ю. О., 2016).

\section{Аналіз останніх досліджень та публікацій.}

Інтегральним показником дії всіх чинників життя на рослинний організм протягом його росту та розвитку є урожайність. За останні 5 років у виробничих умовах в Україні рідко вдавалось отримати понад 2,0 т/ га насіння сої, тоді як генетичний потенціал продуктивності сучасних сортів становить 4,5-5,0 т/га й більше (Іванюк С., 2015, Камінський В. Ф. \& Мосьондз Н. П., 2010), що вимагає удосконалення окремих елементів технології вирощування культури для забезпечення зростання урожайності та якості насіння.

Вагомими чинниками формування високого врожаю насіння сої $є$ сорт і розкриття його потенціалу продуктивності внаслідок інокуляції насіння та мінерального живлення рослини (Іванюк С., 2015; Новицкая Н. В., Джемесюк А. В. 2015; Чорна В. М., 2016). Сорт, на сьогодні, - найдоступніший i найдешевший засіб підвищення урожайності сільськогосподарських культур. У багатьох країнах світу сорти сої на 30-60 \% визначають рівень майбутнього врожаю (Міленко О. Г., 2015). На думку Бабича А. О., насіннєва продуктивність сої зумовлюється генотипом сорту лише на $20 \%$ (Бабич А. О., 2011). Причому кожен сорт може повністю реалізувати свої потенційні можливості лише за оптимальних умов вирощування (Міленко О. Г., 2015). Набагато більше значення мають чинники зовнішнього середовища та технологія вирощування культури (Чорна В. М., 2016).

Урожай і якість насіння сої значною мірою залежать від добрив (Ткаліч І. Д. \& Шепілова Т. П., 2011). Рослини сої потребують збалансованого мінерального живлення сої протягом усієї вегетації. Особливо важливим є оптимальне забезпечення рослин елементами живлення в критичні періоди росту та розвитку: цвітіння-формування бобів. Нестача хоча б одного 3 елементів призводить до абортивності квіток, зав'язей та формування малої кількості недостатньо виповненого насіння (Петриченко В. Ф. та 
ін., 2016). Та найбільш дискусійним залишається питання доцільності застосування азотних добрив. Одні автори вважають, що завдяки азотфіксації, яка проходить у сформованих у симбіозі з ризобіями бульбочках, соя може значно або, навіть, повністю задовольняти свою потребу в азоті завдяки симбіотрофному живленню, що дозволяє вирощувати сою взагалі без внесення або 3 мінімальними дозами азотних добрив (Freeborn J. et all. ., 2001). Інші вчені (Адамень Ф. Ф., 2006; Мельник А. В. \& Романько Ю. О.; 2016, Новицкая Н. В. \& Джемесюк А. В., 2015; Петриченко В. Ф. та ін., 2016) вважають, що формування високих урожаїв сої можливе лише за раціонального поєднання біологічного й технічного азоту для покриття потреб рослин сої. Причому, ефективність останніх залежить від строків їхнього внесення, встановлення оптимальних норм з урахуванням сортових особливостей, глибини загортання, типу й родючості грунту, умов вологозабезпеченості (Ткаліч І. Д. \&Шепілова Т. П., 2011).

Важливим резервом підвищення урожайності сої, завдяки покращеному азотному та фосфорному живленню, є передпосівна обробка насіння мікробними препаратами поліфункціональної дії на основі азотфіксуючих та фосформобілізуючих бактерій (Золотар Ю.В., 2002; Петриченко В. Ф., Кобак С. Я. \& Темрієнко О. О., 2018; Patyka V. P., 2017). Застосування високоефективних штамів бульбочкових бактерій у симбіозі із сучасними сортами сої здатне підвищувати продуктивність останніх на 10-30 \% (Дидович С. В., 2012).

Мета досліджень полягала у виявленні особливостей формування продуктивності сої різних сортів за- лежно від інокуляції насіння та норм i строків внесення мінеральних добрив в умовах Лісостепу правобережного.

\section{Матеріали і методи дослідження.}

Дослідження виконували впродовж 2013 - 2015 pр. в умовах ДПДГ «Саливонківське» Інституту біоенергетичних культур і цукрових буряків НААН на чорноземі типовому малогумусному середньосуглинковому. Уміст гумусу в шарі 0-20 cм $4,56 \%$, у $20-50$ см - 4,27\%. Загального азоту в шарі 0-20 см міститься 0,27-0,30 \%, фосфору - 0,15-0,24 \%, калію - 2,2-2,4\%. Уміст рухомого фосфору за Чиріковим складає 4,45,4 мг/100 г грунту. Система удобрення передбачала вивчення таких варіантів: без добрив (контроль); $\mathrm{P}_{60} \mathrm{~K}_{60}$; $\mathrm{N}_{15} \mathrm{P}_{60} \mathrm{~K}_{60} ; \mathrm{N}_{30} \mathrm{P}_{60} \mathrm{~K}_{60} ; \mathrm{N}_{45} \mathrm{P}_{60} \mathrm{~K}_{60} ; \mathrm{P}_{60} \mathrm{~K}_{60}$ $+\mathrm{N}_{15} ; \mathrm{N}_{15} \mathrm{P}_{60} \mathrm{~K}_{60}+\mathrm{N}_{15} ; \mathrm{N}_{30} \mathrm{P}_{60} \mathrm{~K}_{60}+\mathrm{N}_{15}$. Фосфорні та калійні добрива вносили під основний обробіток грунту, азотні - навесні під культивацію перед сівбою та ув підживлення на відповідних варіантах у фазі бутонізації рослин сої. У дослідах вивчали скоростиглий сорт Вільшанка та середньостиглий сорт Сузір'я, оригінатором яких є ННЦ «Інститут землеробства НАAН».

Агротехніка в досліді - загальноприйнята для умов правобережного Лісостепу України, за винятком чинників, що вивчались. Висівали сою за температури грунту на глибині $10 \mathrm{~cm} 10-12$ С із нормою висіву 700 тис. насінин на 1 га. Сівбу проводили необробленим насінням і насінням, інокульованим фосфонітрагіном. Попередник - пшениця озима. Площа облікових ділянок - $25 \mathrm{~m}^{2}$, повторність - чотириразова. Під час 
проведення досліджень керувались «Основами наукових досліджень в агрономії» (Єщенко В. О., Копитко П. Г. \& Опришко В. П., 2005).

Погодні умови в роки проведення досліджень були різними, що дозволило всебічно схарактеризувати дію досліджуваних чинників на формування рівня врожайності сої. Зокрема, 2013 та 2014 роки характеризувались як сприятливі для росту та розвитку рослин. У вказані роки гідротермічний коефіцієнт (ГТК), залежно від варіанту досліджень, становив, відповідно, 1,2-1,5 та 1,4-1,5, середньодобова температура $-19,1-19,8{ }^{\circ} \mathrm{C}$ та $18,6-19,5^{\circ} \mathrm{C}$, сума активних температур $\left(>10{ }^{\circ} \mathrm{C}\right)-2019,5-2258,7{ }^{\circ} \mathrm{C}$ та $2003,7-2216,7^{\circ} \mathrm{C}$. У 2015 році високі середньодобові температури на фоні низької відносної вологості повітря, а також недостатня кількість атмосферних опадів і нерівномірний їхній розподіл протягом вегетації обмежували реалізацію потенціалу продуктивності рослин сої. У вказаний рік ГТК протягом вегетаційного періоду культури становив 0,6-0,7, середньодобова температура складала 21,1$21,6{ }^{\circ} \mathrm{C}$, сума активних температур $\left(>10{ }^{\circ} \mathrm{C}\right)-2040,5-2324,4{ }^{\circ} \mathrm{C}$, залежно від досліджуваного варіанта.

\section{Результати досліджень та їх обговорення.}

Згідно з проведеними дослідженнями 3 вивчення впливу інокуляції насіння фосфонітрагіном та норм i строків внесення мінеральних добрив на формування врожайності сортів сої Вільшанка та Сузір'я встановлено, що рівень їхньої насіннєвої продуктивності значною мірою залежав від досліджуваних чинників (табл. 1).
У середньому за 2013-2015 pp. максимальну врожайність досліджувані сорти формували за умови поєднання обробки насіння перед проведенням сівби фосфонітрагіном та внесення $\mathrm{N}_{30} \mathrm{P}_{60} \mathrm{~K}_{60}$ в основне удобрення 3 підживленням рослин $\mathrm{N}_{15} \mathrm{y}$ фазі бутонізації, що дозволило отримати на посівах сорту Вільшанка 2,91 т/га зерна, сорту Сузір'я - 3,17 т/га. Проти абсолютного контролю приріст урожаю на цих варіантах становив, відповідно 1,02 та 0,98 т/га або $54,0 \%$ та $44,7 \%$.

Застосування лише мінеральних добрив забезпечувало приріст урожаю в сорту Вільшанка на рівні 0,16-0,65 т/га або 8,5-34,4 \%, у сорту Сузір'я 0,27-0,72 т/га або 12,3-32,9\% за абсолютних контролів відповідно 1,89 та 2,19 т/га. Найвищі прирости були відмічені на варіантах, що передбачали внесення мінеральних добрив у нормі $\mathrm{N}_{30} \mathrm{P}_{60} \mathrm{~K}_{60}$ та підживлення рослин $\mathrm{N}_{15} \mathrm{y}$ фазі бутонізації - у сорту Вільшанка 2,54 т/га, у сорту Сузір'я - 2,91 т/га.

Проведення передпосівної інокуляції насіння фосфонітрагіном сприяло приросту зерна сої на всіх досліджуваних варіантах. На ділянках без внесення добрив прибавка урожаю від інокуляції в сорту Вільшанка складала 0,27 т/га або 14,3 \%, у сорту Сузір'я - 0,24 т/га або 11,0 \%.

Слід зазначити, що обидва досліджувані сорти сої за рівнем приросту насіння подібно реагували як на передпосівну інокуляцію фосфонітрагіном, так і на внесення добрив. У середньому, за 2013 - 2015 рр. урожайність насіння в сорту Вільшанка коливалась у межах від 1,89 до 2,91 т/га, у сорту Сузір'я - від 2,19 до 3,17 т/га.

За результатами проведеного дисперсійного аналізу встановлено частки впливу досліджуваних чинників 
1. Урожайність насіння сої залежно від інокуляції насіння та удобрення, т/га

\begin{tabular}{|c|c|c|c|c|c|c|c|}
\hline \multirow{2}{*}{ Удобрення } & \multirow{2}{*}{ Інокуляція } & \multicolumn{3}{|c|}{ Рік } & \multirow{2}{*}{ Середнє } & \multicolumn{2}{|c|}{ Прибавка } \\
\hline & & 2013 & 2014 & 2015 & & т/га & $\%$ \\
\hline \multicolumn{8}{|c|}{ Сорт Вільшанка } \\
\hline \multirow{2}{*}{ Без добрив } & $6 / \mathrm{i}$ & 2,16 & 1,90 & 1,61 & 1,89 & - & - \\
\hline & $\mathrm{i}$ & 2,51 & 2,22 & 1,74 & 2,16 & 0,27 & 14,3 \\
\hline \multirow{2}{*}{$\mathrm{P}_{60} \mathrm{~K}_{60}$} & $6 / \mathrm{i}$ & 2,32 & 2,08 & 1,76 & 2,05 & 0,16 & 8,5 \\
\hline & $\mathrm{i}$ & 2,76 & 2,48 & 1,97 & 2,40 & 0,51 & 27,0 \\
\hline \multirow{2}{*}{$\mathrm{N}_{15} \mathrm{P}_{60} \mathrm{~K}_{60}$} & $6 / \mathrm{i}$ & 2,49 & 2,21 & 1,85 & 2,18 & 0,29 & 15,3 \\
\hline & $\mathrm{i}$ & 2,81 & 2,52 & 2,06 & 2,46 & 0,57 & 30,2 \\
\hline \multirow{2}{*}{$\mathrm{N}_{30} \mathrm{P}_{60} \mathrm{~K}_{60}$} & $6 / \mathrm{i}$ & 2,54 & 2,41 & 2,04 & 2,33 & 0,44 & 23,3 \\
\hline & $\mathrm{i}$ & 2,99 & 2,865 & 2,245 & 2,70 & 0,81 & 42,9 \\
\hline \multirow{2}{*}{$\mathrm{N}_{45} \mathrm{P}_{60} \mathrm{~K}_{60}$} & $6 / \mathrm{i}$ & 2,67 & 2,54 & 2,19 & 2,47 & 0,58 & 30,7 \\
\hline & $\mathrm{i}$ & 3,08 & 2,89 & 2,223 & 2,73 & 0,84 & 44,4 \\
\hline \multirow{2}{*}{$\mathrm{P}_{60} \mathrm{~K}_{60}+\mathrm{N}_{15}$} & $6 / \mathrm{i}$ & 2,52 & 2,29 & 1,89 & 2,23 & 0,34 & 18,0 \\
\hline & $\mathrm{i}$ & 2,84 & 2,56 & 2,09 & 2,50 & 0,61 & 32,3 \\
\hline \multirow{2}{*}{$\mathrm{N}_{15} \mathrm{P}_{60} \mathrm{~K}_{60}+\mathrm{N}_{15}$} & $6 / \mathrm{i}$ & 2,68 & 2,56 & 2,21 & 2,48 & 0,59 & 31,2 \\
\hline & $\mathrm{i}$ & 3,13 & 2,92 & 2,38 & 2,81 & 0,92 & 48,7 \\
\hline \multirow{2}{*}{$\mathrm{N}_{30} \mathrm{P}_{60} \mathrm{~K}_{60}+\mathrm{N}_{15}$} & $6 / \mathrm{i}$ & 2,75 & 2,61 & 2,27 & 2,54 & 0,65 & 34,4 \\
\hline & $\mathrm{i}$ & 3,21 & 3,06 & 2,457 & 2,91 & 1,02 & 54,0 \\
\hline $\mathrm{HIP}_{0.05}(\mathrm{AБB})$ & - & 0,42 & 0,48 & 0,36 & 0,54 & - & - \\
\hline \multicolumn{8}{|c|}{ Сорт Сузір'я } \\
\hline \multirow{2}{*}{ Без добрив } & $6 / \mathrm{i}$ & 2,40 & 2,21 & 1,95 & 2,19 & - & - \\
\hline & $\mathrm{i}$ & 2,69 & 2,48 & 2,13 & 2,43 & 0,24 & 11,0 \\
\hline \multirow{2}{*}{$\mathrm{P}_{60} \mathrm{~K}_{60}$} & $6 / \mathrm{i}$ & 2,68 & 2,48 & 2,21 & 2,46 & 0,27 & 12,3 \\
\hline & $\mathrm{i}$ & 2,94 & 2,69 & 2,31 & 2,65 & 0,46 & 21,0 \\
\hline \multirow{2}{*}{$\mathrm{N}_{15} \mathrm{P}_{60} \mathrm{~K}_{60}$} & $6 / \mathrm{i}$ & 2,80 & 2,54 & 2,25 & 2,53 & 0,34 & 15,5 \\
\hline & $\mathrm{i}$ & 3,00 & 2,78 & 2,34 & 2,71 & 0,52 & 23,7 \\
\hline \multirow{2}{*}{$\mathrm{N}_{30} \mathrm{P}_{60} \mathrm{~K}_{60}$} & $6 / \mathrm{i}$ & 2,97 & 2,67 & 2,35 & 2,66 & 0,47 & 21,5 \\
\hline & $\mathrm{i}$ & 3,16 & 2,92 & 2,43 & 2,84 & 0,65 & 29,7 \\
\hline \multirow{2}{*}{$\mathrm{N}_{45} \mathrm{P}_{60} \mathrm{~K}_{60}$} & $6 / \mathrm{i}$ & 3,04 & 2,75 & 2,39 & 2,73 & 0,54 & 24,7 \\
\hline & $\mathrm{i}$ & 3,23 & 2,98 & 2,44 & 2,88 & 0,69 & 31,5 \\
\hline \multirow{2}{*}{$\mathrm{P}_{60} \mathrm{~K}_{60}+\mathrm{N}_{15}$} & $6 / \mathrm{i}$ & 2,87 & 2,59 & 2,28 & 2,58 & 0,39 & 17,8 \\
\hline & $\mathrm{i}$ & 3,05 & 2,81 & 2,37 & 2,74 & 0,55 & 25,1 \\
\hline \multirow{2}{*}{$\mathrm{N}_{15} \mathrm{P}_{60} \mathrm{~K}_{60}+\mathrm{N}_{15}$} & $6 / \mathrm{i}$ & 3,12 & 2,81 & 2,45 & 2,79 & 0,60 & 27,4 \\
\hline & $\mathrm{i}$ & 3,36 & 3,12 & 2,57 & 3,02 & 0,83 & 37,9 \\
\hline \multirow{2}{*}{$\mathrm{N}_{30} \mathrm{P}_{60} \mathrm{~K}_{60}+\mathrm{N}_{15}$} & $6 / \mathrm{i}$ & 3,21 & 3,01 & 2,52 & 2,91 & 0,72 & 32,9 \\
\hline & $\mathrm{i}$ & 3,510 & 3,321 & 2,679 & 3,17 & 0,98 & 44,7 \\
\hline $\mathrm{HIP}_{0,05}(\mathrm{AБB})$ & - & 0,42 & 0,48 & 0,36 & 0,54 & - & - \\
\hline
\end{tabular}

*Примітка: б/i - варіанти досліду без застосування інокуляції; i - варіанти досліду із застосуванням передпосівної інокуляції. 
та їхні взаємодії на формування рівня урожайності сої (рис. 1, 2).

Визначено, що удобрення приблизно рівнозначно впливає на насіннєву продуктивність обох сортів - у середньому за 3 роки досліджень дольова частка участі вказаного фактору в сорту Вільшанка складала 46,17 \%, у сорту Сузір'я - 39,88 \%.
За чинником «інокуляція» відмічена більш виразна реакція сортів - частка впливу обробки насіння фосфонітрагіном у формуванні урожайності сорту Вільшанка становила $22,64 \%$, у сорту Сузір'я - 8,74 \%. Вагомим чинником повноти реалізації потенціалу продуктивності сої $є$ погодні умови року, які менш обмежу-

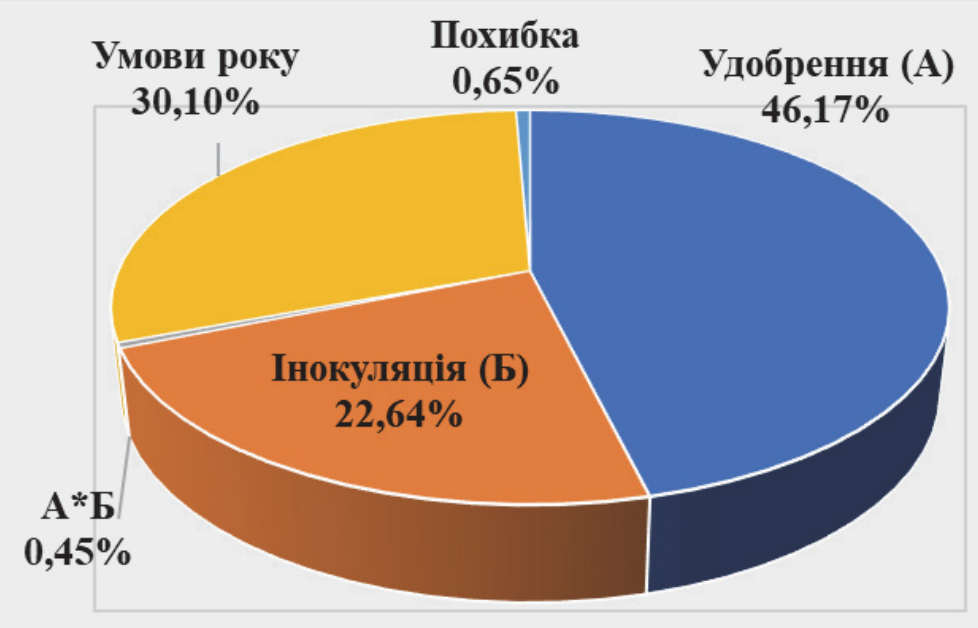

Рис. 1. Частка впливу чинників на формування врожайності сої сорту Вільшанка

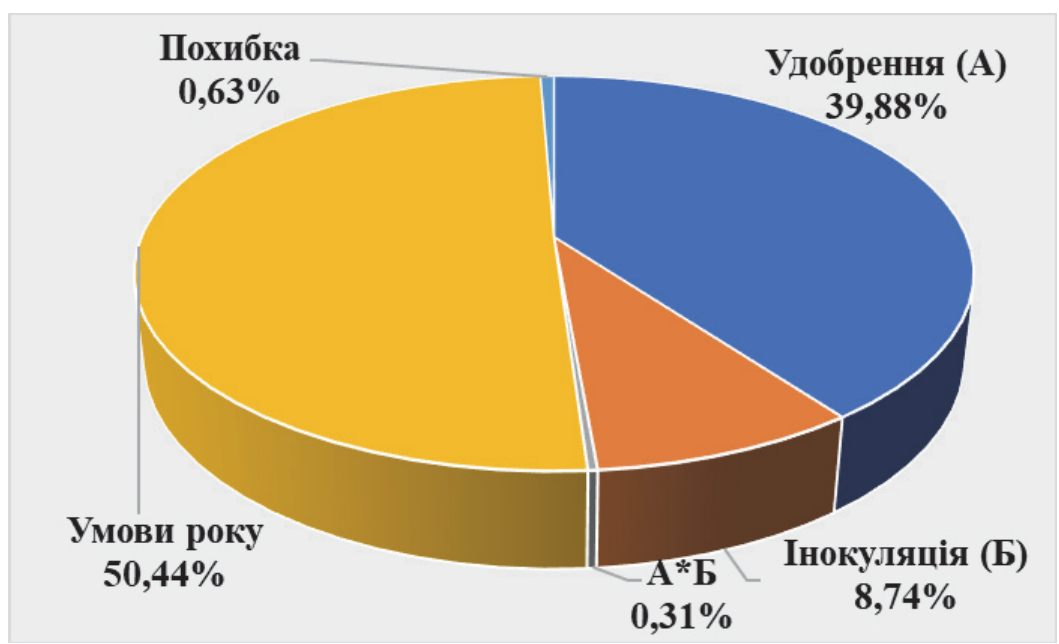

Рис. 2. Частка впливу чинників на формування врожайності сої сорту Сузір'я 
ють реалізацію потенціалу врожайності в сорту Вільшанка $(30,10 \%)$ та $\epsilon$ визначальним чинником досліду в сорту Сузір'я - 50,44 \%.

Зважаючи на біологічні відмінності сортів та їхню реакцію на чинники досліду варто проаналізувати вплив досліджуваних елементів на формування врожайності в цілому в межах трифакторного досліду (рис. 3).

Встановлено, що найбільш істотний вплив на формування рівня врожаю мало удобрення, дольова частка участі якого становить 36,97\%. Погодні умови вегетаційного періоду визначали рівень урожайності на $33,26 \%$, що зумовлено значною залежністю рівня засвоєння рослинами сої поживних елементів із мінеральних добрив від гідротермічного режиму протягом вегетації та підтверджує свідчення авторів про значну роль нерегульованих чинників довкілля на продукційний процес у сої (Іванюк С. В., 2016). Інокуляція насіння визначала формування рівня урожайності на $12,85 \%$, біологічні особливості сорту - на 15,37 \%.
Оскільки останніми роками все чіткіше проявляються кліматичні зміни на фоні глобального потепління, що призводить до значних втрат врожаю, є потреба пошуку залежності між врожайністю сільськогосподарських культур та погодними умовами під час їхньої вегетації, що дозволить виявити найбільш вирішальні гідротермічні чинники впливу (Собко 3. 3. \& Вознюк Н. М., 2018).

Для математичного моделювання впливу погодних умов на формування рівня врожайності сої ми побудували регресійні моделі, які описують вплив середньодобової температури повітря $\left(\mathrm{X}_{1}\right)$, суми активних температур $\left(\mathrm{X}_{2}\right)$, кількості опадів $\left(\mathrm{X}_{3}\right)$ та ГТК $\left(\mathrm{X}_{4}\right)$ на рівень врожайності для сорту Сузір'я:

$$
\begin{gathered}
\mathrm{Y}=5,257+0,389 \mathrm{X}_{1}- \\
-0,006 \mathrm{X}_{2}+0,09 \mathrm{X}_{3}+18,13 \mathrm{X}_{4} \text {; } \\
\text { для сорту Вільшанка: } \\
\mathrm{Y}=3,689-0,594 \mathrm{X}_{1}+0,008 \mathrm{X}_{2} \text {. }
\end{gathered}
$$

Аналіз коефіцієнтів парної кореляції між величиною врожаю насіння сої іа гідротермічними умовами протягом вегетаційного періоду сорту Віль-

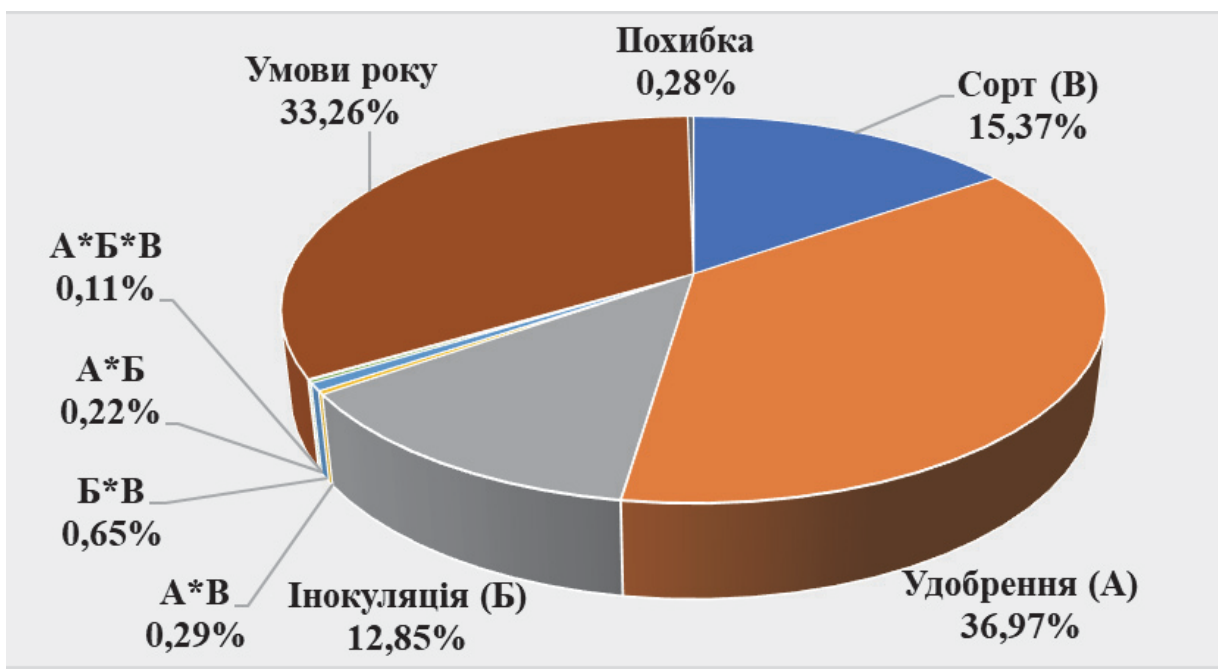

Рис. 3. Частка впливу факторів на формування урожайності сої 
шанка вказує на наявність взаємодій щодо: середньодобової температури повітря $(\mathrm{r}=-0,54$, значний $)$, суми активних температур ( $\mathrm{r}=0,59$, значний $)$, кількості опадів ( $\mathrm{r}=0,49$, помірний) та ГТК ( $\mathrm{r}=0,46$, помірний). У сорту Сузір'я відмічено кореляційні зв'язки між урожайністю та середньодобовою температурою повітря $(\mathrm{r}=-0,67$, значний $)$, кількістю опадів ( $\mathrm{r}=0,72$, сильний) та ГТК (r = -0,69, значний).

\section{Висновки.}

В умовах правобережного Лісостепу України максимальну продуктивність досліджувані сорти формували за умови поєднання обробки насіння перед проведенням сівби фосфонітрагіном та внесення $\mathrm{N}_{30} \mathrm{P}_{60} \mathrm{~K}_{60}$ в основне удобрення та підживлення рослин $\mathrm{N}_{15}$ у фазі бутонізації, що дозволило отримати на посівах скоростиглого сорту Вільшанка 2,91 т/га, середньостиглого сорту Сузір'я - 3,17 т/га. Проти абсолютного контролю приріст урожаю на цих варіантах становив відповідно 1,02 та 0,98 т/га.

\section{References}

1. Adamen, F. F., Verhunov, V. A., Lazer, P. N., Verhunova, Y. N. (2006) Ahrobyolohycheskye osobennosty vozdelbuvanyia soy $\checkmark$ Ukrayne [Agrobiological features of soybean cultivation in Ukraine]. K.: Ahrarna nauka, 456.

2. Babych, A. O. Babych-Poberezhna, A.A. (2011) Selektsiia, vyrobnytstvo, torhivlia i vykorystannia soi u sviti [World's soybean breeding, production, trading and using]. K.: Ahrarna nauka, 548.

3. Didovich S. V. et al. (2012) Biopreparaty v agrotekhnologiyakh vyrashchivaniya zernobobovikh kul'tur. [Biological products in agrotechnologies of growing leguminous crops] Byulleten' Regional'nogo TSNO APP AR Krym: Agromir № 13.8 p. s

4. Ieshchenko, V.O., Kopytko, P.H., Opryshko, V.P. (2005) Osnovy naukovykh doslidzhen v ahronomii [Fundamentals of scientific research in agronomy]. Kyiv: Diia, 288.

5. Zolotar, Yu.V. (2002) Biolohizatsiia tekhnolohii vyroshchuvannia soi [Biologization of soybean growing technologies]. Zbirnyk naukovykh prats Instytutu zemlerobstva UAAN. Kyiv, 2. 60-63.

6. Ivaniuk, S. V., Vilhota, M. V., Zharkova, O. Yu. (2016) Vplyv hidrotermichnykh umov na formuvannia produktyvnosti soi v Umovakh lisostepu Ukrainy [The influence of hydrothermal conditions on soybean productivity formation in conditions of the Forest-Steppe of Ukraine]. Kormy i kormovyrobnytstvo. 82. 21-28.

7. Ivaniuk, S. (2015) Potentsial produktyvnosti soievoho polia [Soybean field productivity potential]. Ahrobiznes sohodni. 21. 50-55.

8. Melnyk, A. V., Romanko, Yu. O. (2016) Urozhainist nasinnia soi zalezhno vid tekhnolohii vyroshchuvannia $v$ umovakh livoberezhnoho lisostepu Ukrainy [Yields of soybean seeds depending on growing technology in conditions of the Left-Bank Forest-Steppe of Ukraine]. Visnyk Sumskoho natsionalnoho ahrarnoho universytetu. Seriia «Ahronomiia i biolohiia». 2 (31). 131-135.

9. Milenko, O. H. (2015) Vplyv ahroekolohichnykh faktoriv na vrozhainist soi [Influence of agroecological factors on soybean productivity]. Molodyi vchenyi. 6 (1). 52-54.

10. Kaminskyi V.F., Mosondz, N.P. (2010) Formuvannia produktyvnosti soi zalezhno vid ahrotekhnichnykh zakhodiv $v$ umovakh pivnichnoho Lisostepu Ukrainy [Soybean productivity formation depending on agrotechnical measures in conditions of the northern Forest-Steppe of Ukraine]. Kormy i kormovyrobnytstvo. 67. 45-50.

11. Novytskaia, N.V., Dzhemesiuk, A.V. (2015) Urozhainost soy $\mathrm{v}$ zavysymosty ot эlementov tekhnolohyy na chernozemakh typychnыkh 
Lesostepy Ukraynu [Soybean yield depending on technology elements on typical chernozems of the Forest-Steppe of Ukraine]. Vestnyk Altaiskoho hosudarstvennoho ahrarnoho unyversyteta, 5 (127). 11-16.

12. Petrychenko, V. F., Kobak, S. Ya., Temriienko, O. O. (2018) Osoblyvosti symbiotrofnoho zhyvlennia ta formuvannia urozhainosti sortiv soi v umovakh Lisostepu pravoberezhnoho [Features of symbiotrophic nutrition and yield formation of soybean varieties in conditions of the Right-Bank Forest-Steppe]. Kormy i kormovyrobnytstvo, 86. 77-86.

13. Petrychenko V. F. at al. (2016) Soia: monohrafiia [Soybean: monograph] Vinnytsia: «Dilo», 400.

14. Sobko, Z.Z., Vozniuk, N.M. (2018) Zalezhnist vrozhainosti silskohospodarskykh kultur vid klimatychnykh ta ahrometeorolohichnykh chynnykiv (na prykladi Rivnenskoi oblasti) [Crop's yields dependence on climatic and agrometeorological factors (on example of Rivne region)]. Naukovi dopovidi NUBiP Ukrainy. 3 (73). http://dx.doi.org/10.31548/ dopovidi2018.03.016 http://journals.nubip.edu.ua/index.php/Dopovidi/article/ view/dopovidi2018.03.016/9498

15. Temriienko, O.O. (2018) Formuvannia produktyvnosti soi zalezhno vid ahrotekhnichnykh pryiomiv vyroshchuvannia v umovakh Lisostepu Pravoberezhnoho [Soybean productivity formation depending on agrotechnical methods of growing in conditions of the Right-Bank Forest-Steppe]. Naukovi dopovidi NUBiP Ukrainy. 3 (73).http:// journals.nubip.edu.ua/index.php/Dopovidi/article/view/10853. DOI: http://dx.doi. org/10.31548/dopovidi2018.03.014

16. Tkalich, I.D., Shepilova, T.P. (2011) Vplyv cposobiv ta strokiv vnesennia mineralnykh dobryv na urozhainist soi [Influence of method and timing of mineral fertilizers application on soybean productivity]. Biuleten Instytutu zernovoho hospodarstva, 40. 50-53.

17. Chorna V. M. (2016) Nasinnieva produktyvnist soi zalezhno vid tekhnolohichnykh pryiomiv vyroshchuvannia v umovakh Lisostepu Pravoberezhnoho [Seed productivity of soybeans, depending on technological methods of growing in the Right-Bank Forest-Steppe]. Kormy i kormovyrobnytstvo, 82. 69-77.

18. Patyka V. P. at al. (2017) Gel preparation risofobite for pre-sowing inoculation of soybean seeds. Guidelines; for ed. Academician of the National Academy of Sciences of the Russian Academy of Sciences. Kyiv: Print Kvik, 2017. 16p.

19. J. Freeborn, D. Holshouser, M. Alley, N. Powel, D. Orcutt (2001) Soybean Yield Response to Reproductive Stage Soil-Applied Nitrogen and Folial-Applied Boron. Agronomy Journal. Vol. 93. № 6. P. 1200-1209.

\section{Vyshnivskyi P. S., Furman O. V. (2020). SOYBEAN PRODUCTIVITY DEPENDING ON ELEMENTS OF GROWING TECHNOLOGY IN THE RIGHT-BANK FOREST-STEPPE OF UKRAINE. PLANT AND SOIL SCIENCE, 11(1): 13-22. https://doi.org/10.31548/ agr2020.01.013}

Abstract. A significant role in solving the problem of vegetable protein deficiency is playing soybeans, modern high-performance varieties of which, with developing and improving of adaptive components its growing technologies, are able to form consistently high yields of high-quality seeds. Among these components, selection of varieties, clarification of fertilizing doses and seed inoculation in accordance with soil and climatic conditions of a particular region, are of great importance.

The purpose of research was to identify features of soybean productivity formation of different varieties depending on seeds inoculation and doses and timing of mineral fertilizers applica- 
tion in conditions of the Right-Bank Forest-Steppe. The experiment was laid during 2013-2015 in conditions of the SERF "Salivonkivske" of the Institute of Bioenergetic Crops and Sugar Beet of NAAS on typical low humus chernozems.

According to the results of research, was established that in conditions of the Right-Bank Forest-Steppe of Ukraine the maximum yields studied hybrids formed under condition of combination seed treatment before sowing by phosphonitragin and application of N30P60K60 like the main fertilizer and extra feeding $\mathrm{N} 15$ in the budding phase, what allowed to obtain at early-ripening variety Vilshanka $2.91 \mathrm{t} / \mathrm{ha}$ and at mid-season variety Suzir'ya-3.17 t/ha. Compared with the absolute control, the yield increase in these variants by 1.02 and $0.98 \mathrm{t} / \mathrm{ha}$, respectively

Key words: soybean, variety, inoculation, top dressing, fertilizers, productivity 